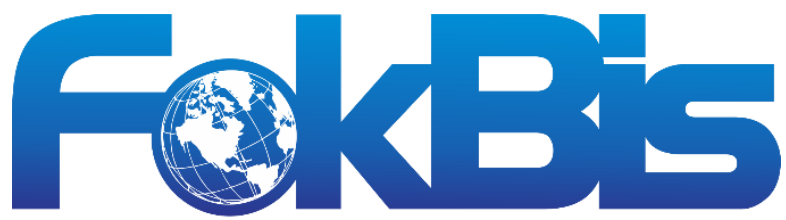

Media Pengkajian Manajemen dan Akuntansi

http://journal.stieputrabangsa.ac.id/index.php/fokbis/index

ISSN: 2623-2480/ P-ISSN: 1693-5209

\section{Analysis of The Influence of Intellectual Capital, Working Capital, And Leverage in Affecting Profitability And Its Relationship on The Firm Value}

\author{
Susanti Widhiastuti ${ }^{1}$, Bobby Ekasaputra ${ }^{2}$, Jayadi Jayadi ${ }^{3}$ \\ ${ }^{1,2,3)}$ Sekolah Tinggi Ilmu Ekonomi IPWI, Jakarta \\ email: santiwidhiastuti@gmail.com ${ }^{1}$
}

\section{Article Information}

\section{History of Article:}

Received: January $13^{\text {th }} 2020$

Accepted: July $16^{\text {th }} 2020$

Published: July $31^{\text {st }} 2020$

\section{DOI:}

10.32639/fokusbisnis.v19i1.614

\begin{abstract}
ABSTRAK
This study aims to analyze the effect of intellectual capital (VAHU), working capital (working capital turnover / WCT), and leverage (DER) in influencing profitability (ROE) in relation to firm value (PBV). The population in this study are companies in the mining, plantation and consumer goods manufacturing industries listed on the Indonesia Stock Exchange from 2014 to 2018 with a total of 40 companies. The sample selection is done using the purposive sampling method and the samples used in this study were 14 companies. This type of research used in this study is a causal type explanatory research that seeks to test the influence of variables in a structural model. The results showed that: 1). Intellectual capital affects the profitability and value of the company, 2). Working capital turnover does not affect the profitability and value of the company, 3). Leverage affects the profitability and value of the company, 4). Profitability affects the value of the company.
\end{abstract}

Keywords: Intellectual capital, Working capital turnover, Leverage, Profitability, Firm Value

\title{
INTRODUCTION
}

The purpose of a company is to maximize the value of the company or wealth for shareholders. Maximizing the value of the company is considered more appropriate as a company's goal because maximizing the value of the company means maximizing the present value of all profits to be received by shareholders in the future. The level of competition between companies, especially in manufacturing and mining industry companies has changed the company to run its business from a business based on labor to a business based on knowledge or by maximizing intellectual capital owned by the company in the form of human capital, and also supported by working capital in the hope can increase the profitability of the company which in this study is measured by Return on Equity (ROE) and also has an impact on increasing the value of the company as measured by Price to Book Value (PBV). The value of the company is also supported by the amount of working capital (Working Capital Turnover (WCT)). The 
value of the company in this study was measured using Price to Book Value (PBV) which illustrates how much the market appreciates the book value of a company's stock because the higher this ratio indicates that the market trusts more in the company's prospects.

Profitability has an important role in evaluating company performance, especially in the perspective of organizational operations and management. Irawati (2006) states that the ratio of profitability is used to measure the efficiency of the use of company assets and the company's ability to operate efficiently. Profitability is chosen as an intervening variable of firm value because intellectual capital, working capital, and leverage can affect profitability as well as affect the firm's value. In addition to profitability, there are other variables that affect the value of the company, namely the size of the leverage owned by the company. In this study leverage is measured by the DER ratio (Debt Equity Ratio). . Leverage can be understood as an estimator of the risks inherent in a company. This means that the greater the leverage indicates the greater the risk of investment. Companies with low leverage ratios have smaller leverage ratios.

Based on empirical data on the influence of intellectual capital, working capital, and leverage in influencing profitability and its relationship to corporate value in manufacturing and mining industry companies, encouraging research in addition to suggestions from previous research that discusses intellectual capital variables (Widhiastuti, 2018 and Nugraha, 2018), working capital (Ruwindas, 2012), leverage (Sujoko \& Subiantoro (2007), profitability (Pratama \& Wiksuana (2016). From the results of previous studies still found several relationships between independent variables (intellectual capital, working capital, leverage and profitability ) which is inconsistent gives a positive influence on the dependent variable (corporate value), as well as on the basis of research recommendations conducted by Widhiastuti and Nugraha (2018), where the suggestion for future researchers is to conduct research using other independent variables that affect profits such as working capital, leverage, and add a period of time, then based on these considerations the author intends to conduct research on the independent variables suggested by previous researchers (Widhiastuti and Nugraha (2018).

\section{LITERATURE REVIEW}

\section{Intellectual Capital}

According to Bontis (1998) intellectual capital is a set of intangibles (resources, abilities and competencies) that drive organizational performance and value creation. The main components revealed in intellectual capital are human capital, structural capital, and relational capital (Zurnali, 2010). Human Capital is the expertise and competency of employees in producing goods and services and their ability to be able to deal well with customers. Human resources capital will increase if the company is able to use the knowledge possessed by its employees (Subkhan and Citraningrum, 2010).

\section{Working Capital}

Working capital is an investment of a company in short-term assets such as cash, securities, inventories, and receivables, Brigham and Houston (2006: 131). Funds as working capital are funds used to finance the company's operational activities, especially those that have a short term. So working capital is all current assets or short-term assets that are often used in the daily operations of the company.

\section{Working Capital Turnover}

Working capital turnover is a ratio used in measuring the effectiveness of a company's working capital during a certain period. Husnan (2007), states that an indicator of good working capital management is the existence of working capital efficiency. The efficiency of working capital can be seen from the working capital turnover, receivable turnover, and inventory turnover. Working capital turnover starts from the time cash is invested in the working capital component until it returns to cash. The shorter the 
working capital turnover period, the faster the turnover so that working capital turnover is higher and the company is more efficient which ultimately increases profitability. In this study the authors analyze the efficiency of working capital in terms of aspects of working capital turnover.

\section{Leverage}

Leverage is the magnitude of the use of debt as a source of corporate funding (Sudana, 2009: 23). By using leverage, a company can not only gain profits but can also cause a company to suffer losses, because financial leverage means that the company imposes risk to shareholders so that it affects stock returns (Weston and Copeland, 1999).

\section{Profitability}

According to Syafri (1999: 304) Profitability of a company is the company's ability to make a profit through all existing capabilities and sources such as sales, cash, capital, number of employees, number of branches and so on. In this study the profitability ratio is measured by return on equity (ROE). Return on equity (ROE) is a ratio that shows how much the company's ability to generate net income for return of equity to shareholders.

\section{Firm Value}

According to Suad (2000) what is meant by firm value is the price that prospective buyers are willing to pay if the company is sold. Firm value can provide prosperity to shareholders if the company's stock price increases. The higher the share price, the higher the shareholder prosperity. So that if the value of the company is high, the owner's prosperity will also be high, because the high value of the company represents a high stock price and optimal company performance. So that the company's value illustrates how well or poorly management manages its wealth, this can be seen from the measurement of financial performance obtained. Firm value in this study was measured using Price to Book Value (PBV). PBV illustrates how much the market values the book value of a company's shares (Sunarsih and Mendra, 2012).

\section{Hypotheses Development}

\section{H1: Intellectual Capital Affects Company Profitability}

According to Pramestiningrum (2013) defines intellectual capital as an intangible asset that is a resource of knowledge, which can affect the performance of a company both in decision making for now and future benefits. From research conducted by Widhiastuti and Nugraha (2018) and Bentoen (2012) explains that intellectual capital affects the profitability of the company.

\section{H2: Working Capital Affects Company Profitability}

Working capital is all current assets or short-term assets that are often used in the daily operations of the company. Efficiency of working capital, one of which can be seen from the working capital turnover. Working capital turnover is a ratio used in measuring the effectiveness of a company's working capital during a certain period.

From a study conducted by Siwi (2005), Ruwindas (2012), Ambarwati, et al (2015) explained that working capital had a significant positive effect on company profitability. Meanwhile according to Santoso (2013) explains that working capital turnover does not significantly influence the Company's profitability.

\section{H3: Leverage Affects Company Profitability}

Leverage is an important tool in measuring the effectiveness of the use of corporate debt. Leverage is the magnitude of the use of debt as a source of corporate funding (Sudana, 2009: 23). Leverage in this study is calculated using the DER (Debt to Equity Ratio) ratio, because this ratio measures the proportion of funds sourced from debt to finance the company's assets. 
Research conducted by Pratama \& Wiksuana (2016) explains that partial leverage has a significant positive effect on Firm Value and Profitability partially has a significant positive effect on Firm Value.

\section{H4: Intellectual Capital Affects Firm Value}

According to Pramestiningrum (2013) defines intellectual capital as an intangible asset that is a resource of knowledge, which can affect the performance of a company both in decision making for now and future benefits.

Research conducted by Widhiastuti \& Nugraha (2018), Widarjo (2013), Chahyadi and Putra (2012), Randa \& Solon (2012) explained that intellectual capital had a significant positive effect on firm value. While research conducted by Suhendah (2012), Sunarsih \& Mendra (2012) and Widarjo (2011) explained that intellectual capital had no effect on Firm Value.

\section{H5: Working Capital Affects Firm Value}

Working capital is all current assets or short-term assets that are often used in the daily operations of the company. Efficiency of working capital, one of which can be seen from the working capital turnover. Working capital turnover is a ratio used in measuring the effectiveness of a company's working capital during a certain period.

Research conducted by Siwi (2005), Ruwindas (2012), Ambarwati, et al (2015) explains that working capital has a significant positive effect on company profitability. Meanwhile according to Santoso (2013) explains that working capital turnover does not significantly influence the Company's profitability.

\section{H6: Leverage Affects Companty Value}

Leverage is an important tool in measuring the effectiveness of the use of corporate debt. Leverage is the magnitude of the use of debt as a source of corporate funding (Sudana, 2009: 23). Leverage in this study is calculated using the DER (Debt to Equity Ratio) ratio, because this ratio measures the proportion of funds sourced from debt to finance the company's assets.

Research conducted by Pratama \& Wiksuana (2016) explains that leverage partially has a significant positive effect on firm value. Meanwhile, according to Prasetyorini (2013), Wibowo \& Wartini (2012), Sujoko \& Subiantoro (2007), explained that leverage has no significant effect on firm value.

\section{H7: Profitability Affects Firm Value}

According to Syafri (1999: 304) Profitability of a company is the company's ability to make a profit through all the capabilities and existing sources such as sales, cash, capital, number of employees, number of branches and so on.

Research conducted by Dewi and Wirajaya (2013), Hamidi, et al (2015) explains that leverage partially has a significant positive effect on firm value. Meanwhile, according to Hermuningsih (2012), Apriada and Suardhika (2016) explained that profitability had no significant effect on firm value

\section{RESEARCH METHOD}

The type of data used in this study is secondary data, namely the annual financial statements of the Manufacturing and Mining Industries that were listed on the Indonesia Stock Exchange during the period 2014 - 2018. Sources of data collected directly came from the IDX's official website through www.idx.co.id.

This study consists of three independent variables or independent variables (X), namely intellectual capital (VAHU), working capital (Working Capital Turnover), and leverage (DER), as well as two dependent 
variables or dependent variables consisting of one intervening variable, namely profitability ( $R O E$ ) by using the symbol $(\mathrm{Z})$ and one dependent variable, the firm value (PBV) with the symbol (Y).

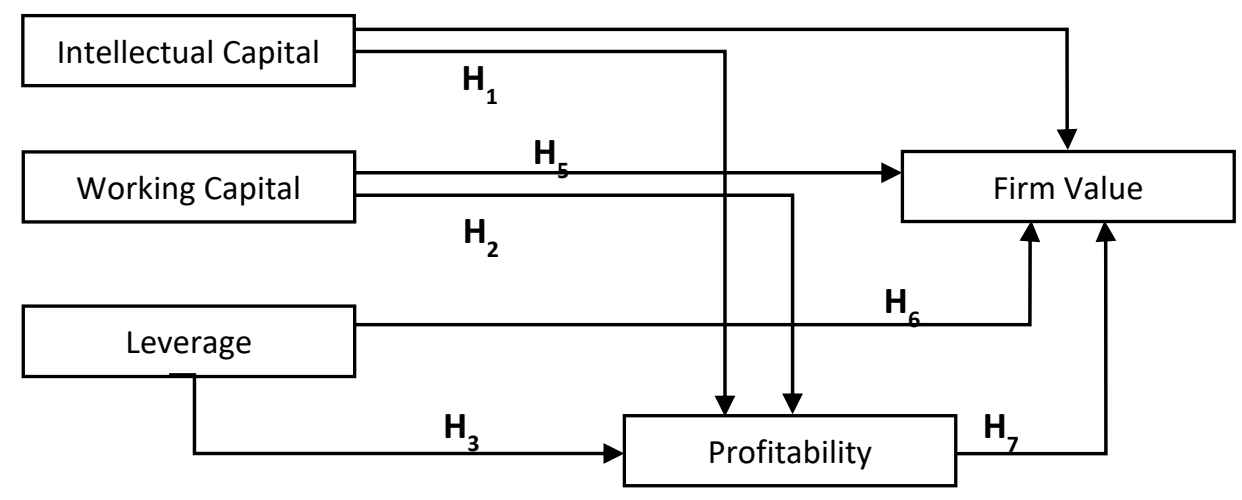

Figure 1. Research model

\section{Research Samples}

The population in this study are companies that are included in the Consumer Goods Manufacturing, Pharmaceutical, Plantation and Mining Industry Sector which are listed on the Indonesia Stock Exchange for the period 2014 - 2018 with a total of 40 companies. The sample selection is done using the purposive sampling method, namely:

a) Companies that consistently publish annual reports for the period 2014-2018

b) Companies that during 2014 - 2018 have dividend payout ratios

c) Availability of complete company financial statements for 2014-2018, both physically and through the website.

The sample used in this study amounted to 14 companies from 40 companies listed in the Consumer Goods Manufacturing, Pharmaceutical, Plantation and Mining sectors.

\section{Analysis Method}

The analytical method used is descriptive statistical analysis and multiple linear regression analysis consisting of classical assumption tests (normality, multicollinearity, heteroscedasticity, and autocorrelation), model tests (coefficient of determination $\mathrm{R} 2$, statistical test $\mathrm{F}$, and $\mathrm{t}$ test)

\section{RESULT AND DISCUSSION}

\section{Descriptive Analysis}

Descriptive analysis aims to find out the data description of research results. This analysis is presented in the form of mean (mean), standard deviation (standard deviation) minimum value, and maximum value of intellectual capital (VAHU), working capital (Working Capital Turnover), leverage (DER), profitability (ROE) and company value (PBV).

The average value (mean), standard deviation (standard deviation) of the minimum value, and the maximum value of intellectual capital, working capital, leverage, profitability and company value are calculated based on the period of 2014 - 2018 with 14 companies listed on the Indonesia Stock Exchange. 
Table 1.Descriptive and Variable Analysis Results

\begin{tabular}{|l|r|r|r|r|r|}
\hline Keterangan & VAHU & $\begin{array}{c}\text { Working } \\
\text { Capital } \\
\text { Turnover }\end{array}$ & DER & ROE & PBV \\
\hline $\mathrm{N}$ & 70 & 70 & 70 & 70 & 70 \\
\hline Min. & 2.33 & 1.31 & 0.03 & 0.02 & 0.14 \\
\hline Max. & 9.41 & 43.49 & 3.60 & 0.33 & 8.74 \\
\hline Mean & 4.81 & 6.09 & 0.88 & 0.14 & 2.05 \\
\hline $\begin{array}{l}\text { Std. } \\
\text { Deviation }\end{array}$ & 1.72 & 5.78 & 0.65 & 0.07 & 1.67 \\
\hline
\end{tabular}

Table 2. Recapitulation of Company Intellectual Capital Data from Descriptive Analysis Results

\begin{tabular}{|l|c|c|c|c|c|c|c|}
\hline \multicolumn{1}{|c|}{ Keterangan } & 2014 & 2015 & 2016 & 2017 & 2018 & $2014-2018$ & $\begin{array}{c}\text { Kode } \\
\text { Perusahaan }\end{array}$ \\
\hline Jumlah sample (N) & 14 & 14 & 14 & 14 & 14 & 70 & \\
\hline Nilai Mn. & 2.42 & 2.94 & 3.04 & 2.49 & 2.33 & 2.33 & LSIP \\
\hline Nilai Max. & 9.41 & 9.02 & 9.07 & 8.60 & 8.26 & 9.41 & KLBF \\
\hline Mean & 4.60 & 4.62 & 4.55 & 5.18 & 5.12 & 4.81 & \\
\hline Std. Deviasi & \multicolumn{7}{|l|}{} \\
\hline
\end{tabular}

Table 3. Recapitulation of Company Working Capital Turnover Data From Descriptive Analysis Results

\begin{tabular}{|l|c|c|c|c|c|c|c|}
\hline \multicolumn{1}{|c|}{ Keterangan } & 2014 & 2015 & 2016 & 2017 & 2018 & 20142018 & $\begin{array}{c}\text { Kode } \\
\text { Peru sahaan }\end{array}$ \\
\hline Jumlah sample (N) & 14 & 14 & 14 & 14 & 14 & 70 & \\
\hline Nilai Min. & 3.03 & 2.35 & 1.91 & 1.9 & 1.31 & 1.31 & AGII \\
\hline Nilai Max. & 43.69 & 20.71 & 11.76 & 16.50 & 13.95 & 43.69 & AKRA \\
\hline Mean & 8.04 & 6.48 & 5.51 & 4.98 & 5.49 & 6.09 & \\
\hline Std. Deviasi & \multicolumn{7}{|c|}{} \\
\hline
\end{tabular}

Table 4. Recapitulation of Company Leverage Data From Descriptive Analysis Results

\begin{tabular}{|l|c|c|c|c|c|c|c|}
\hline \multicolumn{1}{|c|}{ Keterangan } & 2014 & 2015 & 2016 & 2017 & 2018 & $2014-2018$ & $\begin{array}{c}\text { Kode } \\
\text { Perusahaan }\end{array}$ \\
\hline Jumlah sample (N) & 14 & 14 & 14 & 14 & 14 & 70 & \\
\hline Nilai Min. & 0.07 & 0.06 & 0.03 & 0.10 & 0.18 & 0.03 & UNTR \\
\hline Nilai Max. & 3.60 & 2.24 & 2.27 & 2.27 & 2.33 & 3.60 & KLBF \\
\hline Mean & 1.05 & 0.92 & 0.082 & 0.78 & 0.84 & 0.88 & \\
\hline Std. Deviasi & \multicolumn{7}{|l}{} \\
\hline
\end{tabular}


Table 5. Recapitulation of Company Profitability Data From Descriptive Analysis Results

\begin{tabular}{|l|c|c|c|c|c|c|c|}
\hline \multicolumn{1}{|c|}{ Keterangan } & 2014 & 2015 & 2016 & 2017 & 2018 & $2014-2018$ & $\begin{array}{c}\text { Kode } \\
\text { Perusahaan }\end{array}$ \\
\hline Jumlah sample (N) & 14 & 14 & 14 & 14 & 14 & 70 & \\
\hline Nilai Min. & 0.05 & 0.03 & 0.02 & 0.03 & 0.04 & 0.02 & AGl \\
\hline Nilai Max. & 0.33 & 0.22 & 0.21 & 0.33 & 0.31 & 0.33 & PTBA \\
\hline Mean & 0.16 & 0.13 & 0.13 & 0.13 & 0.14 & 0.14 & \\
\hline Std. Deviasi & \multicolumn{7}{|c|}{} \\
\hline
\end{tabular}

Table 6. Recapitulation of Company Value Data from Descriptive Analysis Results

\begin{tabular}{|c|c|c|c|c|c|c|c|}
\hline Keterangan & 2014 & 2015 & 2016 & 2017 & 2018 & 20142018 & Kode Perusah aan \\
\hline Jumlah sample (N) & 14 & 14 & 14 & 14 & 14 & 70 & \\
\hline Nilai Min. & 0.19 & 0.14 & 0.14 & 0.28 & 0.63 & 0.14 & INKP \\
\hline Nillal Max. & 8.74 & 5.66 & 5.70 & 5.70 & 5.37 & 8.74 & KLBF \\
\hline Mean & 2.59 & 1.68 & 2 & 206 & 193 & 205 & \\
\hline 5td. Deviasi & & & & & & 167 & \\
\hline
\end{tabular}

\section{Classical Assumption Test}

Based on the results of the normality test, all points spread around and approach the diagonal lines. This shows that the research data shows normal data distribution. Multicollinearity test results on the independent variables obtained tolerance values on research variables above 0.1 and VIF values below 10 so that it can be said there is no correlation between independent variables.

Heterokedastisitas test seen points spread without forming a specific pattern and spread above and below the number 0 on the $Y$ axis. Thus the data in this study did not occur heteroscedasticity. For autocorrelation test of $\mathrm{dw}$ value of 1.84 lies between $1.70<\mathrm{dw}<2.97$ where there is no autocorrelation (first capital) and dw value of 1.68 does not lie between $1.74<\mathrm{dw}<2.26$ where it occurs autocorrelation (second capital).

\section{Model Testing}

The linear regression equation model in this study is formulated in the following equation:

$R O E=\alpha+\beta 1 V A H U+\beta 2 W C T+\beta 3 D E R$

$P B V=\alpha+\beta 4 V A H U+\beta 5 W C T+\beta 6 D E R+\beta 7 R O E$ 


\section{First Model Testing}

The first model test is a test of the effect of intellectual capital (VAHU), working capital (WCT), and leverage (DER) on profitability (ROE).

\section{Tabel 7.Adjusted $\mathbf{R}^{2}$ Test of VAHU, WCT, DER toward ROE}

\begin{tabular}{|l|c|c|c|c|}
\hline $\begin{array}{l}\text { Mode } \\
1\end{array}$ & $\mathrm{R}$ & R Square & $\begin{array}{c}\text { Adjusted R } \\
\text { Square }\end{array}$ & $\begin{array}{c}\text { Std. Error of } \\
\text { the Estimate }\end{array}$ \\
\hline 1 & $.396^{\mathrm{a}}$ & .157 & .118 & .06310 \\
\hline
\end{tabular}
a. Predictors: (Constant), DER, WCT, VAHU
b. Dependent Variable: ROE

Source: Secondary Data Processing (2019)

From the table above, the coefficient of double determination Adjusted $R 2=0.118$. It states that the independent variables (VAHU, WCT, DER) have an effect of $11.8 \%$ on the dependent variable (ROE).

Tabel 8. Test of Sig F VAHU, WCT, and DER toward ROE

\begin{tabular}{|c|r|r|r|r|r|r|}
\hline \multicolumn{10}{|c|}{ ANOVA $^{\text {' }}$} \\
Madel & & $\begin{array}{c}\text { Sum of } \\
\text { Squares }\end{array}$ & df & Mean Square & F & Sig. \\
\hline 1 & Regression & .049 & 3 & .016 & 4.083 & $.010=$ \\
& Residual & .263 & 66 & .004 & & \\
& Total & .312 & 69 & & & \\
\hline
\end{tabular}

a. Predictors: (Constant), DER, WCT, VAHU

b. Dependent Variable: ROE

Source: Secondary Data Processing (2019)

From the table above, the significance value for the $F(0.01)$ test is smaller than 0.05 and the calculated $F$ value $(4.083)$ is greater than the $F$ table value $(2.744)$ so that this proves that $\mathrm{Ho}$ is rejected and $\mathrm{Ha}$ is accepted so that it can be said that financial performance variables (VAHU, Working Capital Turnover, and DER) simultaneously and can significantly affect company profitability.

Tabel 9. Model Testing of VAHU, WCT, DER toward ROE

\begin{tabular}{|c|c|c|c|c|c|c|}
\hline \multicolumn{7}{|c|}{ Coefficients ${ }^{\mathrm{a}}$} \\
\hline \multirow{2}{*}{\multicolumn{2}{|c|}{ Model }} & \multicolumn{2}{|c|}{ Unstandardized Coefficients } & \multirow{2}{*}{$\begin{array}{c}\begin{array}{c}\text { Standardized } \\
\text { Coefficients }\end{array} \\
\text { Beta } \\
\end{array}$} & \multirow[b]{2}{*}{$t$} & \multirow[b]{2}{*}{ Siq. } \\
\hline & & $\mathrm{B}$ & Std. Error & & & \\
\hline \multirow[t]{4}{*}{1} & (Constant) & .067 & .027 & & 2.443 & .017 \\
\hline & VAHU & .019 & .005 & .478 & 3.412 & .001 \\
\hline & MCT & .001 & .001 & .105 & .847 & .400 \\
\hline & DER & -.031 & .014 & -.297 & -2.204 & .031 \\
\hline
\end{tabular}

a. Dependent Variable: ROE

Source: Secondary Data Processing (2019) 
Based on the table above we get the equation:

ROE $=0.067+0.019 \mathrm{VAHU}+0.001 \mathrm{WCT}-0,031 \mathrm{DER}$

\section{Second Model Testing}

The second test model is a test of the influence of intellectual capital (VAHU), working capital (WCT), leverage (DER) and profitability (ROE) on the value of the company (PBV).

Tabel 10. Adjusted R $^{2}$ Test of VAHU, WCT, DER, and ROE toward PBV

Model Summary

\begin{tabular}{|l|l|r|r|r|}
\hline $\begin{array}{l}\text { Mode } \\
1\end{array}$ & $\mathrm{R}$ & $\mathrm{R}$ Square & $\begin{array}{c}\text { Adjusted R } \\
\text { Square }\end{array}$ & $\begin{array}{c}\text { Std. Error of } \\
\text { the Estimate }\end{array}$ \\
\hline 1 & $.707^{\mathrm{a}}$ & .500 & .469 & 1.21837 \\
\hline
\end{tabular}

a. Predictors: (Constant), ROE, DER, WCT, VAHU

Source: Secondary Data Processing (2019)

From the table above we get the coefficient of double determination Adjusted $R 2=0.469$. It states that the independent variables (VAHU, WCT, DER, ROE) have an effect of $46.9 \%$ on the dependent variable (PBV).

Table 11. Test of Sig F VAHU, WCT, DER and ROE toward PBV

\begin{tabular}{|ll|r|r|r|r|c|}
\multicolumn{7}{|c|}{ ANOVA $^{\text {b }}$} \\
\hline Model & & Sum of & df & Mean Square & F & Sig. \\
\hline 1 & Regression & 96.462 & 4 & 24.116 & 16.246 & $.000^{=}$ \\
& Residual & 96.488 & 65 & 1.484 & & \\
& Total & 192.950 & 69 & & & \\
\hline
\end{tabular}

a. Predictors: (Constant), ROE, DER, WCT, VAHU

b. Dependent Variable: PBV

Source: Secondary Data Processing (2019)

From the above table, the significance value obtained for the $F(0,000)$ test is smaller than 0.05 and the calculated $F$ value $(16,246)$ is greater than the $F$ table value $(2,513)$ so that it can be said that the financial performance variable (VAHU, Working Capital Turnover, DER and ROE) can simultaneously affect the value of the company (PBV). 
Table 12. Model Testing of VAHU, WCT, DER and ROE toward PBV

\begin{tabular}{|c|c|c|c|c|c|c|}
\hline \multicolumn{7}{|c|}{ Coefficients ${ }^{3}$} \\
\hline \multirow{2}{*}{\multicolumn{2}{|c|}{ Model }} & \multicolumn{2}{|c|}{ Unstandardized Coefficients } & \multirow{2}{*}{$\begin{array}{c}\begin{array}{c}\text { Standardized } \\
\text { Coefficients }\end{array} \\
\text { Beta } \\
\end{array}$} & \multirow[b]{2}{*}{$t$} & \multirow[b]{2}{*}{ Siq. } \\
\hline & & $\mathrm{B}$ & Std. Error & & & \\
\hline \multirow[t]{5}{*}{1} & (Constant) & -1.430 & .554 & & -2.580 & .012 \\
\hline & VAHU & .251 & .115 & .258 & 2.192 & .032 \\
\hline & WCT & .001 & .028 & .003 & .034 & .973 \\
\hline & DER & .740 & .280 & .286 & 2.646 & .010 \\
\hline & ROE & 11.759 & 2.377 & .473 & 4.948 & 000 \\
\hline
\end{tabular}

a. Dependent Variable: PBV

Source: Secondary Data Processing (2019)

Based on the table above we get the equation:

$Y=-1.430+0.251 \mathrm{VAHU}+0.001 \mathrm{WCT}+0.740 \mathrm{DER}+11.759 \mathrm{ROE}$

\section{Hypoytheses Testing}

\section{H1: Intellectual Capital Affects Profitability}

Based on the calculation results in table 4 above it is found that the calculated $t$ value $(3,412)>t$ table value $(1,996)$ at $\alpha 0.05(\mathrm{df}=67)$ or the significance value $(0.001)<\alpha(0.05)$. Thus $\mathrm{Ho}$ is rejected and $\mathrm{Ha}$ is accepted. So it can be concluded that there is a significant influence between Intellectual Capital (VAHU) on Profitability (ROE).

\section{H2: Working Capital Affects Profitability}

Based on the calculation results in table 4 above it is found that the calculated $t$ value $(0.847)<t$ table value (1.996) at $\alpha 0.05(\mathrm{df}=67)$ or the significance value $(0.400)>\alpha(0.05)$. Thus $\mathrm{Ho}$ is accepted and $\mathrm{Ha}$ is rejected. So it can be concluded that there is no significant effect between Working Capital (Working Capital Turnover) on Profitability (ROE).

\section{H3: Leverage Affects Profitability}

Based on the calculation results in table 4 above it is found that the calculated $t$ value $(-2,204)>t$ table value $(1,996)$ at $\alpha 0.05(\mathrm{df}=67)$ or the significance value $(0.031)<\alpha(0.05)$. Thus $\mathrm{Ho}$ is rejected and $\mathrm{Ha}$ is accepted. So it can be concluded that there is a significant effect between Leverage (DER) on Profitability (ROE).

\section{H4: Intellectual Capital Affects Company Value}

Based on the calculation results in table 4 above, it is found that the calculated $t$ value $(2,192)>t$ table $(1,997)$ at $\alpha 0.05(\mathrm{df}=66)$ or the significance value $(0.032)<\alpha(0.05)$. Thus Ho is rejected and Ha is accepted. So it can be concluded that there is a significant influence between Intellectual Capital (VAHU) on Company Value (PBV).

\section{H5: Working Capital Affects Company Value}

From the calculation results of table 4 above, it is found that the calculated $t$ value $(0.034)<t$ table $(1,997)$ at $\alpha 0.05(\mathrm{df}=66)$ or the significance value $(0.973)>\alpha(0.05)$. Thus Ho is accepted and $\mathrm{Ha}$ is rejected. So it 
can be concluded that there is no significant effect between Working Capital (Working Capital Turnover) on Company Value (PBV).

\section{H6: Leverage Affects Company Value}

From the calculation results of table 4 above, it is found that the calculated $t$ value $(2,646)>t$ table value $(1,997)$ at $\alpha 0.05(\mathrm{df}=66)$ or the significance value $(0.010)<\alpha(0.05)$. Thus $\mathrm{Ho}$ is rejected and $\mathrm{Ha}$ is accepted. So it can be concluded that there is a significant influence between Leverage (DER) on Company Value (PBV).

\section{H7: Profitability Affects Company Value}

From the calculation results of table 4.15 above it was found that the calculated $t$ value $(4,948)>t$ table value $(1,997)$ at $\alpha 0.05(\mathrm{df}=66)$ or the significance value $(0,000)<\alpha(0.05)$. Thus $\mathrm{Ho}$ is rejected and $\mathrm{Ha}$ is accepted. So it can be concluded that there is a significant effect between profitability (ROE) on Company Value (PBV).

\section{Effect of intellectual capital (VAHU) on profitability (ROE)}

The significance value of the VAHU variable on profitability (ROE) is 0.001 , so the significance value is smaller than 0.05 . Therefore it can be concluded that at the $95 \%$ confidence level there is a significant influence between intellectual capital (VAHU) on company profitability (ROE). Intellectual capital is an intangible asset owned by a company and can create profits that have an impact on increasing the value of the company. Added value in the form of intellectual capital is a measure that reflects the contribution of employees and management to value creation. The higher added value that employees can contribute to the company means ensuring higher dividends for shareholders, and increased investment for company development due to increased profitability (Pulic, 2008). Profit obtained by the company can increase the value of the company. With the profit that is owned allows the company to more freely increase the value of the company.

The results of research conducted by Widhiastuti \& Nugraha (2018) and Wijaya (2012) show that there is an influence between intellectual capital on company profitability. This is in line with the results of research which shows that there is a positive and significant influence between intellectual capital on company profitability. This means that the higher the intellectual capital, the higher the profitability of a company.

\section{Effect of working capital (Working Capital Turnover) on profitability (ROE)}

The significance value of the Working Capital Turnover variable on profitability (ROE) is 0.400 , so the significance value is greater than 0.05 . Therefore it can be concluded that at the $95 \%$ confidence level there is no significant effect between Working Capital Turnover (WCT) on company profitability (ROE). This insignificant situation can be influenced by internal and external factors of the company. Just as sales declined substantially which resulted in operating profit also decreased, increased costs became a factor supporting declining operating profit margins and also expenses which also increased such as general and administrative expenses, marketing and exploration expenses which caused operating profit margins on capital turnover insignificant work. In addition, the source of funds can be obtained by the company through its own capital, company profits (profits), short-term debt and long-term debt. Company management must need to try and maintain balance in regulating the cycle of working capital turnover, because in the management of working capital itself there are some contradictions experienced by the company, namely between working capital that focuses on efforts to maintain liquidity and working capital that focuses on efforts to gain profits (profitability). Profitability is the company's ability to generate profits in relation to sales, total assets and own capital which is often used to measure the 
efficiency of capital use of a company by comparing profits with capital used in operations. Therefore, a large profit does not guarantee or is not a measure that the company can carry out its life continuously. If the company only focuses on its liquidity by only providing funds without investing in other assets that can provide additional income will cause low profits, because the area of operation of the company is small or few will cause losses. Vice versa, if the company only focuses on profitability only by providing only a few liquid tools, it will reduce creditor confidence. That is for the company's management, it must be able to balance working capital between company liquidity and company profitability, so as not to cause problems for the company and achieve high levels of efficiency by using its working capital.

The results of research conducted by Ambarwati, et al (2015) and Azlina (2009) show that there is a significant influence between working capital turnover on company profitability. While the results of research conducted by Santoso (2013) and Reimeinda, et al (2016) showed that there was no significant effect between working capital turnover on company profitability. Therefore the results of this study are not in line with the research conducted by Ambarwati, et al (2015) and Azlina (2009).

\section{Effect of Leverage (DER) on profitability (ROE)}

The significance value of the Leverage (DER) variable against profitability (ROE) is 0.031 , so the significance value is smaller than 0.05 . Therefore it can be concluded that at the $95 \%$ confidence level there is a negative and significant effect between leverage (DER) on company profitability (ROE). Leverage is an important tool in measuring the effectiveness of the use of corporate debt. By using leverage, a company can not only gain profits but can also cause a company to suffer losses, because financial leverage means that the company imposes risk to shareholders so that it affects stock returns (Weston and Copeland, 1999). The use of excessive debt will reduce the benefits received from the use of debt because the benefits received are not proportional to the costs incurred, so that a low proportion of debt can increase the value of the company and conversely an increase in debt can reduce the value of the company. Leverage has a negative effect on company profitability, this is because an increase in debt will increase the risk of bankruptcy and financial distress. This financial difficulty will reduce company profits which can ultimately reduce the value of the company. In the results of this study leverage has a negative and significant effect on the profitability of the company, that is, companies in funding their assets tend to use debt rather than using their own capital (internal financing) that comes from retained earnings and share capital.

The results of research conducted by Sujoko \& Subiantoro (2007) show that there is a negative and significant influence between leverage on corporate profitability. While the results of research conducted by Wibowo \& Wartini (2012) show that there is no significant effect between leverage on corporate profitability. Therefore the results of this study are in line with the research conducted by Sujoko \& Subiantoro (2007).

\section{Effect of intellectual capital (VAHU) on firm value (PBV)}

The significance value of the DER variable to the company value (PBV) is 0.032 , so the significance value is smaller than 0.05 . Therefore it can be concluded that at the $95 \%$ confidence level there is a significant influence between intellectual capital (VAHU) on the value of the company (PBV). Intellectual capital directly affects the value of the company. This means the market gives a higher valuation to companies that have higher intellectual capital. Intellectual capital has a positive effect on the company's financial performance. Solikhah et al. (2010) states that companies that are able to manage their intellectual resources efficiently will create value added and competitive advantages which will lead to an increase in the company's financial performance. The findings of this study indicate that market / investor appreciation in a company is based more on non-physical resources owned by the company with an emphasis on intellectual resources owned by the company. The company is said to have good value if the company's performance is also good. The value of the company can be reflected in the price of its shares, if the value of the shares is high, it can be said that the value of the company is also good Gapensi (1996) 
in Rahcmawati (2007). Company value in this study was measured using Price to Book Value (PBV). PBV illustrates how much the market values the book value of a company's shares. The higher this ratio, shows that the market increasingly believes in the prospects of the company. The higher the price book value, the higher the level of market confidence in the company's prospects, it will be an attraction for investors to buy it. So the demand for these shares rises, then pushes the company's stock price up.

The results of research conducted by Putra \& Cahyadi (2012) and Randa \& Solon (2012) show that there is a significant influence between intellectual capital on firm value. While research conducted by Widhiastuti \& Nugraha (2018), Sunarsih \& Mendra (2012) shows that there is no significant influence between intellectual capital on firm value. Therefore the results of this study are in line with research conducted by Putra \& Cahyadi (2012) and Randa \& Solon (2012).

\section{Effect of working capital (Working Capital Turnover) on firm value (PBV)}

The significance value of the Working Capital Turnover variable against company value (PBV) is 0.973 , so the significance value is greater than 0.05 . Therefore it can be concluded that at the $95 \%$ confidence level there is no significant effect between Working Capital Turnover on the value of the company (PBV). This insignificant situation can be influenced by internal and external factors of the company. Just as sales declined substantially in 2014 to 2018 which resulted in operating income to decline, costs that increased to factors supporting operating profit margins decreased, as well as other expenses which also increased such as general and administrative expenses, marketing expenses and exploration which causes operating profit margins to decrease and has an effect on working capital turnover which is not significant.

The results of research conducted by Azlina (2009) and Ruwindas (2012) stated that the level of working capital turnover affects profitability. This shows the effectiveness of the use of working capital in the company because the higher the level of working capital turnover the more effective the use of working capital. The faster the working capital rotates, the greater the profits that can be achieved by a company to increase profitability. But this is not in line with the results of research conducted by Santoso (2013) and Remeida, et al (2016) which state that working capital turnover has no significant effect on Company Profitability.

In this study, profitability acts as a mediating variable where the results of research conducted by Pratama \& Wiksuana (2016) and Dewi \& Wirajaya (2013) show that there is a positive and significant effect between profitability on firm value. The higher profitability of the company will also increase earnings per share of the company. An increase in earnings per share of the company will make investors interested in investing their capital by buying company shares. With so many investors buying company shares, it will raise the price of the company's shares so that it will increase the company's value. Therefore, from the results of this study, the results of a study conducted by Santoso (2013) and Remeida, et al (2016) stated that working capital turnover had no effect on company profitability.

\section{Effect of Leverage (DER) on Company Value (PBV)}

The significance value of the DER variable to the company value (PBV) is 0.010 , so the significance value is smaller than 0.05 . Therefore it can be concluded that at the $95 \%$ confidence level there is a significant influence between leverage (DER) on the value of the company (ROE). Leverage is a ratio that measures how much a company uses funding that comes from debt (financial leverage) (Brigham et al, 2006). To meet the need for funds to be used by the company to finance the company's assets to support the continuity of the company's operational activities, funding can also be obtained from external loans from the company so that the company can benefit from the results of its business activities. With a good debt management and the company can still maintain its profitability stability, this will have an impact on increasing market confidence in the company because of good debt management supported by stable company profitability so that the company's value can continue to increase.

The results of research conducted by Pratama \& Wiksuana (2016) show that there is a positive and significant influence between leverage on firm value. While the results of research conducted by 
Prasetyorini (2012) shows that there is no significant effect between leverage on company profitability. Therefore the results of this study are in line with the research conducted by Pratama \& Wiksuana (2016).

\section{Effect of Profitability (ROE) on Company Value (PBV)}

The significance value of the profitability variable (ROE) to the company value (PBV) is 0,000 , so the significance value is less than 0.05 . Therefore it can be concluded that at the $95 \%$ confidence level there is a significant effect between profitability (ROE) on company value (PBV). In this study, profitability acts as a mediating variable where the results of research conducted by Pratama \& Wiksuana (2016) and Dewi \& Wirajaya (2013) show that there is a positive and significant effect between profitability on firm value. The higher profitability of the company will also increase earnings per share of the company. An increase in earnings per share of the company will make investors interested in investing their capital by buying company shares. With so many investors buying company shares, it will raise the price of the company's shares so that it will increase the company's value.

The results of research conducted by Pratama \& Wiksuana (2016) and Dewi \& Wirajaya (2013) show that there is a positive and significant effect between profitability on firm value. While the results of research conducted by Hermuningsih (2012) shows that there is an indirect effect on firm value. Therefore the results of this study are in line with research conducted by Pratama \& Wiksuana (2016) and Dewi \& Wirajaya (2013).

\section{CONCLUSION}

a) There is a positive and significant effect between intellectual capital on profitability.

b) There is no significant effect between working capital turnover on company profitability.

c) There is a negative and significant effect between leverage on profitability.

d) There is a positive and significant influence between intellectual capital on company value.

e) There is no significant effect between working capital turnover on company value. the value of the company.

f) There is a positive and significant effect between leverage on firm value.

g) There is a positive and significant effect between profitability on firm value.

For companies need to approach investors or shareholders in order to be willing to accept the delay in dividend payments. This is intended so that companies get funds for development without going through debt or funds from outside the company which certainly requires higher costs compared to retained earnings.

For future researchers, the coefficient of determination results obtained from the analysis of the first regression equation ( $\mathrm{Z}$ ) is only $11.8 \%$. The small coefficient of determination means that the ability of the independent variable in explaining the variation of the dependent variable is very limited. So the results obtained in this study by placing profitability as an intervening variable still do not contribute optimally, so it is necessary to add variables in future studies.

This research is only conducted on companies listed on the Indonesia Stock Exchange, so more research needs to be done for companies listed on LQ 45. In addition to Human Capital (VAHU) Future research needs to add or include other intellectual capital elements such as Structural Capital and Customer Capital, because both of these elements can contribute to increasing the value of the company. Develop relevant variables that can increase the value of the company and increase the number of companies and years of observation. 


\section{REFERENCE}

Ambarwati, N. S., Yuniarta, G. A., AK, S., \& SINARWATI, N. K. (2015). Pengaruh modal kerja, likuiditas, aktivitas dan ukuran perusahaan terhadap profitabilitas pada perusahaan manufaktur yang terdaftar di bursa efek Indonesia. JIMAT (Jurnal IImiah Mahasiswa Akuntansi) Undiksha, 3(1).

Apriada, K., dan Suardhika, M.S. 2016. Pengaruh Struktur Kepemilikan Saham, Struktur Modal, dan Profitabilitas Pada Nilai Perusahaan. Bali: E- Jurnal Ekonomi dan Bisnis Universitas Udayana 5.2 : 201- 218.

Azlina, N. (2009). Pengaruh tingkat perputaran modal kerja, struktur modal dan skala perusahaan terhadap profitabilitas. PEKBIS (Jurnal Pendidikan Ekonomi Dan Bisnis), 1(2), 107-114.

Bontis, N. (1998). Intellectual capital: an exploratory study that develops measures and models. Management decision., Vol. 36 No. 2, pp. 63-76.

Brigham, F. E., \& Joel, F. H. (2006). Dasar-dasar Manajemen Keuangan. Buku 1 Edisi Kesepuluh. Jakarta: Salemba Empat.

Citraningrum, D. P. (2010). Pengaruh IC terhadap Kinerja Keuangan Perusahaan Perbankan Periode 20052007. Jurnal Dinamika Akuntansi, 2(1).

Harahap, S. S. (1999). Analisa Kritis Atas Laporan Keuangan. Edisi Pertama. PT. Raja Grafindo Persada. Jakarta.

Hermuningsih, S. (2012). Pengaruh profitabilitas, size terhadap nilai perusahaan dengan sruktur modal sebagai variabel intervening. Jurnal siasat bisnis, 16(2), 232-242.

Husnan, S. (2000). Manajemen Keuangan Teori dan Penerapan, Edisi Ketiga. Yogyakarta: UPP AMP YKPN.

Irawati, S. (2006). Manajemen Keuangan. Bandung: Pustaka.

Pramestiningrum. (2013). "Pengaruh Intellectual Ca ital Terhada Kinerja Perusahaan Sektor Keuangan ang Terdaftar di Bursa Efek Indonesia (BEI) Tahun 2009-2011”. Universitas Diponegoro, Semarang.

Prasetyorini, B.F. (2013). Pengaruh Ukuran Perusahaan, Leverage, Price Earning Ratio dan Profitiabilitas Terhadap Nilai Perusahaan. Jurnal Ilmu Manajemen (JIM), 1(1).

Pratama, I. G. B. A., \& Wiksuana, I. G. B. (2016). Pengaruh ukuran perusahaan dan leverage terhadap nilai perusahaan dengan profitabilitas sebagai variabel mediasi. E-Jurnal Manajemen Universitas Udayana, 5(2).

Pulic, A. (1998). Measuring the performance of intellectual potential in knowledge economy. In 2nd McMaster Word Congress on Measuring and Managing Intellectual Capital by the Austrian Team for Intellectual Potential (pp. 1-20).

Putra, I. G. C. (2012). Pengaruh Modal Intelektual Pada Nilai Perusahaan Perbankan yang Go Public di Bursa Efek Indonesia. Jurnal Ilmiah Akuntansi dan Humanika, 2(1).

Randa, F. D. A. S., \& Solon, S. A. (2012). Pengaruh modal intelektual terhadap nilai perusahaan. Jurnal Sistem Informasi Manajemen dan Akuntansi, 10(1), 24-27.

Reimeinda, V. (2016). Analisis Pengaruh Modal Kerja terhadap Profitabilitas pada Industri Telekomunikasi di Indonesia. Jurnal Berkala IImiah Efisiensi, 16(3). 
Ruwindas, D. K. (2011). Pengaruh Modal Kerja Terhadap Profitabilitas Perusahaan (Studi Kasus pada CV Dandy Handycraft Tasikmalaya). Skripsi, Bandung: Fakultas Ekonomi Universitas Widyatama.

Santoso, C. E. (2013). Perputaran modal kerja dan perputaran piutang pengaruhnya terhadap profitabilitas pada PT. Pegadaian (PERSERO). Jurnal EMBA: Jurnal Riset Ekonomi, Manajemen, Bisnis dan Akuntansi, 1(4).

Sudana, I Made. 2009. Manajemen Keuangan : Teori dan Praktek. Surabaya: Airlangga University Press.

Sunarsih, N. M., \& Mendra, N. P. Y. (2012). Pengaruh modal intelektual terhadap nilai perusahaan dengan kinerja keuangan sebagai variabel intervening pada perusahaan yang terdaftar di Bursa Efek Indonesia. Simposium Nasional Akuntansi XV, 1(2).

Weston. J. F., \& Thomas E. C. (1997). Manajemen Keuangan. Jilid 2.Edisi Kesembilan. Jakarta: Binarupa Aksara.

Wibowo, A., \& Wartini, A. (2012). Efisiensi Modal Kerja, Likuiditas dan Leverage Terhadap Profitabilitas pada Perusahaan Manufaktur di BEI. Semarang: Fakultas Ekonomi, Universitas Negeri Semarang.

Widarjo, W. (2011). Pengaruh modal intelektual dan pengungkapan modal intelektual pada nilai perusahaan yang melakukan Initial Public Offering. Jurnal Akuntansi dan Keuangan Indonesia, 8(2), 157-170.

Widhiastuti, S., \& Nugraha, R. S. (2019). Pengaruh Modal Intelektual, Biaya Promosi, dan Perputaran Persediaan dalam Mempengaruhi Profit Serta Implikasinya Terhadap Nilai Perusahaan. Jurnal Manajemen Kewirausahaan, 15(2), 183-192.

Wirajaya, A., \& Dewi, A. S. M. (2013). Pengaruh struktur modal, profitabilitas dan ukuran perusahaan pada nilai perusahaan. E-Jurnal Akuntansi Universitas Udayana, 4(2), 358-372. 